Article

\title{
Communicating and Visualising Urban Planning in Cold War Berlin
}

\author{
Christoph Bernhardt and Kathrin Meissner * \\ Department for Historical Research, IRS-Leibniz Institute for Research on Society and Space, 15537 Erkner, Germany; \\ E-Mails: christoph.bernhardt@leibniz-irs.de (C.B.), kathrin.meissner@leibniz-irs.de (K.M.) \\ * Corresponding author
}

Submitted: 15 March 2020 | Accepted: 17 April 2020 | Published: 26 June 2020

\begin{abstract}
This article analyses the dynamics of communication, specifically with regard to the significance of visualisations in urban planning between the two competing political regimes of East and West Germany in divided Berlin (1945-1989). The article will demonstrate the ways in which planners on either side of the Iron Curtain were confronted with matters unique to their own political contexts and conditions for public communication, as well as how they faced similar challenges in fields of urban renewal and negotiating public participation. The post-war decades in Berlin were marked by strong planning dynamics: large-scale reconstruction after WWII and the 'showcase character' of political confrontation and competition. In this context, new strategies of communicating urban planning to the public were developed, such as large-scale development plans, public exhibitions and cross-border media campaigns. Paradigmatic shifts during the mid-1970s generated new discourses about urban renewal and historic preservation. The new focus on small-scale planning in vivid and inhabited inner-city neighbourhoods made new forms of communication and public depiction necessary. In the context of social and political change as well as growing mediatisation, planning authorities utilised aspects of urban identity and civic participation to legitimise planning activities. The article traces two small-scale planning projects for neighbourhoods in East and West Berlin and investigates the interrelation of visual communication instruments in public discourses and planning procedures during the 1980s, a period that prominently featured the new strategy of comprehensive planning. Furthermore, the article highlights the key role of micro-scale changes in the management of urban renewal along both sides of the wall and the emergence of neighbourhood civil engagement and participation.
\end{abstract}

\section{Keywords}

Berlin; civic participation; communication strategy; planning history; public negotiation; small-scale planning; urban renewal; visualising planning

\section{Issue}

This article is part of the issue "Visual Communication in Urban Design and Planning: The Impact of Mediatisation(s) on the Construction of Urban Futures" edited by Gabriela Christmann (Leibniz Institute for Research on Society and Space, Germany), Christoph Bernhardt (Leibniz Institute for Research on Society and Space, Germany) and Jörg Stollmann (TU Berlin, Germany).

(C) 2020 by the authors; licensee Cogitatio (Lisbon, Portugal). This article is licensed under a Creative Commons Attribution 4.0 International License (CC BY).

\section{Introduction}

This article examines the transformation of communicative strategies and visual instruments in urban planning over a long-term, historical perspective in order to contribute a more comprehensive understanding of the ongoing transition of "cities on paper" (Lee \& Weiß, 2019) to a digital planning culture while set against the back- ground of major transformations over the course of the 20th century. It focuses on the emergence of new communicative and visual practices in urban planning in divided post-war Berlin while paying special attention to the 1970s and 1980s. The study examines the usage of several media varieties, from sketches and wallpapers to posters in projects of urban planning on both sides of the Wall; all of which is further embedded within an 
overarching analysis of the socio-political context of urban planning in East and West Berlin during the Cold War (Warnke, 2009).

The article expands on earlier research concerning the emergence of new practices and visual instruments of communication in urban planning in the 20th century, which was developed by planning historian Robert Freeman and others with regard to the role of planning exhibitions and visual tools in European and US urban planning around 1910. At that time, as Freestone highlights, "the exhibition was establishing a visuality of bird's eye view maps, plans, diagrams and pictures as a very distinctive part of the planner's professional toolkit" (Freestone, 2018, p. 199). Freestone's remark addresses the exhibition as a new communicative instrument in urban planning, the various types of visualisations, and the planners' practices ("toolkit"). He localises these key components of 'mediatisation' (Krotz, 2007) in urban planning within the specific historical context of 1910, in which this distinctive type of visual communication emerged for the first time (Bodenschatz \& Kress, 2017).

Along with widening the temporal scope to the postWWII period as well as analysing a variety of practices and visual devices beyond plans and exhibitions, the article's empirical content will be guided by questions regarding the theory of communication (Selle, 1996; Wakeman, 2014), such as: Who was 'sending' and who was 'receiving' messages concerning urban planning project; who was able and/or permitted to speak; which channels, visual instruments and strategies of communication were used and who decided what questions would be discussed? Exploring this set of questions for both political systems provides a cross-cultural analysis of emergent patterns of visualisation and communication in urban planning during the late 20th century from an East-West comparative perspective. The article begins with a reflection on the fundamental political, ideological and institutional framework of Berlin's urban development during the Cold War Era. After examining the cultural shift in society and planning during the 1970s, the article introduces two case studies in urban planning from both sides of the divided city in the 1980s, which serve as empirical examples of the practical implementation of public communication and visual strategies, and as representations of their own paradigmatic distinctions relative to their social-political environments. In it, the position of individual actor groups will be analysed to provide information about questions initially raised about communication relations and decision making.

\section{Berlin's Special Urban Pathway in the Post-WWII Period}

Following the end of WWII, the German capital was terribly destroyed. As such, Berlin entered into a special pathway of urban development, which differed significantly from those adopted across other large cities around the world. The emergence of the two antago- nist states - the Federal Republic of Germany (FRG) and the socialist German Democratic Republic (GDR), both established in 1949-along with the construction of the Wall between the two states and around West Berlin in 1961 contextualised urban planning and development in the metropolitan area for more than four decades. Both sides were characterised by their virtually stagnant population growth, highly thinned-out industry and an extraordinarily low dynamic of suburban sprawl. Divided into two antagonistic political units, the city found itself in a situation of limited self-governance under control of the four Allies, the US, USSR, Britain and France, as well as an apparent normalisation of everyday life while undergoing a constant, far-reaching social and economic transformation (Bernhardt, 2020). At the frontline of the Cold War, urban planning became a battlefield of propaganda and agitation between the two political systems and their respective ideologies. While planning for urban growth had been a major feature of planning during the first part of the 20th century and continued as such in most Western cities during the economic boom between the 1950s and 1970s (the trentes glorieuses, or Wirtschaftswunder), in Berlin, it played only a minor role: In West Berlin, expansive urban development was strictly limited by the Wall, while the socialist East German regime, seeking to distance itself from the influence of Western suburban sprawl, gave priority to projects featuring compact urban design.

Contrastingly, the two main periods and paradigms of urban planning in Berlin during the Cold War were marked by specific foci of planning and building, media and communication strategies. In the first twentyfive years, until around 1970, the reconstruction of the inner-urban housing stock and "great plans" to transform the city centre into a new political landscape were developed along both sides of the border within an increasingly hostile political climate (Wittmann-Englert, 2015). They triggered a top-down planning culture, largescale bird's eye visualisations and one-way communication in which the urban population was permitted to function as nothing more than an audience (Bernhardt, 2020). As Klemek observed, at that time "quiescence was characteristic in West Berlin, even among residents directly affected by redevelopment schemes" (Klemek, 2011, p. 117). Popular media, especially local radio stations and newspapers, presented key projects, such as East Berlin's Stalinallee (Geist \& Kürvers, 1989), the first large-scale housing project, which was constructed east of Alexanderplatz in the early 1950s in the new style of socialist realism, imported directly from the USSR. On the other side of the border, messages of modernisation and political superiority praised the new West Berlin motorway (Stadtautobahn), which was in keeping with the spirit of US highway planning. This symbol of the Western automotive age from 1954 onwards was designed and publicly presented as an "image of the future" (Zukunftsbild; Seehausen, 2015, p. 117). By contrast, contemporary media only rarely echoed critical comments 
of citizens, as in the prominent and controversial case of the Kaiser Wilhelm Gedächtniskirche (Kress, 2014) which set a powerful landmark in the emerging new West Berlin city centre around Kurfürstendamm and the train station, Zoologischer Garten. After the construction of the Berlin Wall in 1961, the situation in terms of planning culture changed only gradually. During this time, strategic projects were realised to create a new socialist capital city centre on the East side and a cultural centre West of Potsdamer Platz with iconic buildings such as, Scharoun's Philharmony and the State Library as well as Mies van der Rohe's New National Gallery (Hoffmann-Axthelm, 2000).

\section{The Cultural Shift of the 1970 s}

The second period and paradigm of planning in postWWII Berlin emerged from the late 1960s onwards in the context of a growing institutional regularisation of Berlin's status as a divided city in formal agreements between the four Allies and the two German governments (Barclay, 2012). This period is typically referred to as the transition to 'urban renewal' (behutsame Stadterneuerung) and presented as a narrative of public intellectual critique initiated by Jane Jacobs (1961), Alexander Mitscherlich (1965) and others as well as bottom-up protests from citizens groups and rebellious students (Schubert, 2014; Warnke, 2009). However, this narrative oversimplifies the transformation in society and planning, as it neglects the broad variety of actors and new trends in urban policies, which resulted in a profound cultural shift in the theories and practices of planning. In West Berlin, it was especially leading architects from the Technical University including, Peter Josef Kleihues and Matthias Ungers, as well as the department of monument protection in the municipal administration, which developed new forms of thinking and visualising the city, particularly with regard to the old inner-urban quarters (Stimmann, 2009). At the same time, as early as 1970, East Berlin planners such as Manfred Zache, developed pioneering concepts for inner-urban renewal, which broke with established practices of destruction (Kahlschlagsanierung; Zache, 2000). These were only two initiatives within a broad reform movement, which also marked a turn towards "signs and signification processes" in urban planning (Hauser, 2018, p. 231).

From the late 1970 s, on small-scale urban planning and the new principle of urban renewal accompanied the intense usage of visual instruments for public information and involvement. Comprehensive planning and new means of communication-later described as the "communicative turn" (Healey, 1992)-generated controversial debates in expert discourses (Albers, 2006). Therein, planners reflected the role of civic society as more than just involving the audience by passive notification, but active participation (Wehland, 1983). The main purpose of urban renewal was intended to change existing living conditions either by modernisation and renovation of historical structures, or by destruction and reconstruc- tion. Thus, communication strategies tended to integrate the affected people, including inhabitants, tradespersons and owners via the pursuit of two goals. First, to raise legitimisation and approval for the project and second, to keep and promote the urban identity of the civic society within their urban environment. In practice, East and West Berlin planning municipalities provided information campaigns and supported citizens' interests in participating. Visual elements on posters, brochures and newspapers supported the written information, which addressed citizens directly to attend the public events, where they could articulate their opinions to experts and political representatives.

Since the planning profession acknowledged how relevant the "imageability" (Freestone, 2015) of the urban environment was in the turn from the 1960s to 1970 s, visualisations were not only meant for pure illustration of urban visions, but they were subjective and socially constructed perceptions of space. The idea that visualisations are products of and reflect aspects of identity, narratives and urban discourses provided new approaches for planners to use visualisations differently (Mook, 2013).

The main challenge of the planning culture in the late 1970s involved grappling with a variety of new planning aspects: Accomplishing projects successfully meant to develop and implement renewal strategies, to serve the multiple requirements, to integrate and satisfy more stakeholders and actor groups, and to set tight but realistic timeframes. Additionally, formal requirements varied according to the categorisation of the planning projects, such as redevelopment areas (Sanierungsgebiete) or town planning programmes (Städtebauprogramme). Therein, small-scale projects often served as pilots for new functional strategies, such as sustainable or community welfare renewal, or as political representations demonstrating power and progress.

Consequently, the communication strategies varied. Designated redevelopment areas and their small-scale subdivisions comprised clear local areas, groups of affected people, and made functional authorities more comprehensible for citizens. Here, special regulations defined public communication and citizen involvement more precisely (Stimmann, 2009). Initiated by planning authorities, various local actors, including planning offices, district boards and social associations, implemented intense on-site work in the neighbourhood(s) to establish more direct contact. Although media reports and public announcements in local newspapers were used, customised visual campaigns such as leaflets or posters prevailed as communicative tools. By comparison, large programmes addressed broader issues with the general public, including the modernisation of infrastructures, management of housing shortages, and meeting social needs. Communication was primarily executed via media. Such visual instruments ranged from photographs, images, drafts and reports to exhibition models and contributions in architectural competitions. 


\section{Public Communication and Negotiation in 1980s Socialist Planning Culture in East Berlin}

While previous research approaches described the planning system and culture in the GDR as a strict topdown, institutionalised and one-dimensional structure of negotiation and decision-making practices with a uniform, uncritical public (Pollack \& Rink, 1997), more recent approaches emphasise the relevance of counter public spheres, 'loopholes' within formal GDR structures (e.g., church, culture institutions and mass organisations) as well as informal networks (Engler, 2012; Jarausch, 2008). GDR socialism was based upon the principles of Democratic Centralism and the subordination of individual interests for the common good of socialist society. In other words, the propagated conformity of interests from the leading party, state government, citizen representatives and even society itself prevented any conflicts of interest. Thus, a critical public sphere was neither necessary nor possible. Since the early 1970s the GDR constitution (originally passed in 1968 and updated in 1974) and several laws highlighted the relevance of society in planning participation and strengthened local political administration and its representatives to foster more direct contact and interactions. Still, the scope of civic society's influence on decision-making processes remained limited. However, by the 1980 s, civic society developed a stronger, more prominent voice in public discourses, with groups of actors formulating their interests more loudly, which helped to further engage political activity, even against the government (Betker \& Bräuer, 2006).

In East Berlin, urban planning since the late 1970s can be characterised by the strong influence on local political authorities in municipal districts. According to preparations for the 750-year jubilee of Berlin in 1987, the Berlin Programme of 1976 announced wide construction ambitions, such as the extension of symbolic architecture as a capital city, the resolution of housing problems and the arrangements for the jubilee itself. As a result, planning authorities declared complex reconstruction zones across a number of inhabited areas, predominantly in central districts, including Prenzlauer Berg, Friedrichshain and Mitte. Additionally, pilot projects (e.g., Arnimplatz) were installed, where communicative measures related to the public negotiation process were tested (Stimmann, 1985).

Generally, the practical implementation and realisation of planning projects were the responsibility of district councils. Here, several stakeholders within the planning practice, including the construction sector, housing administration and installed task forces, worked closely together, where their principle task was to report to the district council's political authorities. The proper procedure regarding urban renewal projects was comprised of internal arrangements and preparations between planning authorities on national and city level as well as the district council. Following the completion of agreements and scheduling the planning project, lo- cal representatives shared relevant public information with the people and neighbourhoods affected by the proposed changes via notice boards, posters, public displays or in assemblies. Formal objections to the proposed plans could be articulated as written submissions (Eingaben) or petitions. Citizens then filed these statements with the appropriate planning authority, which would then respond to stated concerns. Generally, this written communication was more widely practiced than public communication, which often replaced direct dialogues (Mühlberg, 2004). Though, other mechanisms of public communication were also utilised, which included extraordinary council sessions, assembly inputs (Wahlkreisaktivberatung), on-site visits and face-to-face criticism sessions. Here, the so-called public dialogue consisted of a selected audience, which was mostly assigned to representatives of civic society from the house community (Hausgemeinschaft), housing borough or electoral district. Civic participation was seen as both the "right and duty" of every citizen who was expected to participate in so-called democratic elections and actively articulate their concerns to state authorities (Habitat DDR, 1976). In the GDR, in-fact public and unbiased negotiation processes concerning planning projects were not accepted and the influence from civic representatives was limited. Visual instruments did not have a significant relevance. Active involvement of civic society in urban planning largely existed in the areas of producing planning quotes and accomplishing state-approved DIY tasks such as undertaking repairs as well as planting and maintaining cultivation. Here, the government initiated civic and collective work as a joint commitment towards the achievement of socialism. Political programmes as part of mass organisations propagated various types of collective civic engagement, such as awards, contests and initiatives, broadly in media campaigns, like the campaign promoted by the Mach Mit journal. In it, visualisations demonstrated and promoted citizen participation.

For East Berlin planning, the case of a backyard conversion in Oderberger Street 15/17 in 1980-1981 shows an exceptional dealing within the afore-mentioned structures of GDR planning culture and East Berlin urban renewal, which can be viewed retrospectively as a pioneering project that involved public negotiation, civic participation and the use of visual communication instruments. The housing block was located in the historic inner-city district Prenzlauer Berg, which was situated within the closest proximity to the Berlin Wall. While the district's housing structure faced tremendous urban decay as well as an enormous lack of green and recreational areas, the social structure of the neighbourhood was comprised of long-established Berlin inhabitants as well as low-income earners, such as students, artists and young people. Everyday life in the neighbourhood was vibrant and eclectic, and could, to some extent, be characterised by its unique bond to the urban environment. Starting in 1978-1979, two parallel ambitions evolved to convert the unused overgrown and rubbish-strewn back- 
yard. On the one side, planning authorities balanced between the construction of a grocery store and workshops for the construction industry, which would facilitate local DIY repairs and modernisation activities. On the other side, a small group of inhabitants intended to improve their unsatisfying living situation by converting the backyard into a playground and green space. Encouraged by the aforementioned Mach Mit campaign, the inhabitants in Oderberger Street 15/17 sought to plant greenery and establish a playground for children in an effort to create a public space for the benefit of the neighbourhood.

Analyses of archival documents ascertained the communication relations as follows: Since 1979, the district municipality was aware of the inhabitants' ambitions as represented in the many letters submitted on the matter, and it adapted their plans to combine workshops and playground installations. However, they did not correspond to the inhabitants' area layout (see Figure 1). On occasion of spontaneous tree felling works in summer 1981, neighbourhood representatives initiated the first interaction between them and the municipality. More precisely, the housing borough committee (Wohnbezirksausschuss), the formal representative institution of the neighbourhood community, requested information from the council representative.

The option to submit written objections via submissions and petitions was extensively used. Given the extensive use of written submissions and petitions concerning resident objections to projects at this time, a number of visualisations are available and take two common forms. In the first set, photos of the courtyard depicted inadequate conditions and supported arguments for a swift conversion process, while in the second form, maps were drafted as propositions for possible conversions of the space. The function of the visual materials highlighted the written objections and citizens' demands and demonstrates their commitment to engaging in the planning process. Additionally, in the submission letter, the neighbourhood initiative emphasises their willingness to open communication channels as well as to take part in a joint conversion process. Although we cannot trace the documents back to the original author(s) of the initiative who drew the maps nor can we determine whether they received help from planning professionals, it's clear that the small group of neighbours were artists who possessed a creative affinity. The physical material of the submitted drafts take the form of copying paper, which could indicate a blueprint method for maintaining principles of proportionality (see Figure 2). Since the initiative used the housing borough committee to submit their objections in an appropriate manner, it is possible that support was obtained from other active members within or close to this local representative institution. However, it traces the strong social bondage in this neighbourhood and district.

Subsequently, the intense commitment of the neighbourhood initiative in written and visualised forms led to the adoption of more transparent practices in the state's planning procedures: first, by letter correspondence, and second, through dialogue formats, such as

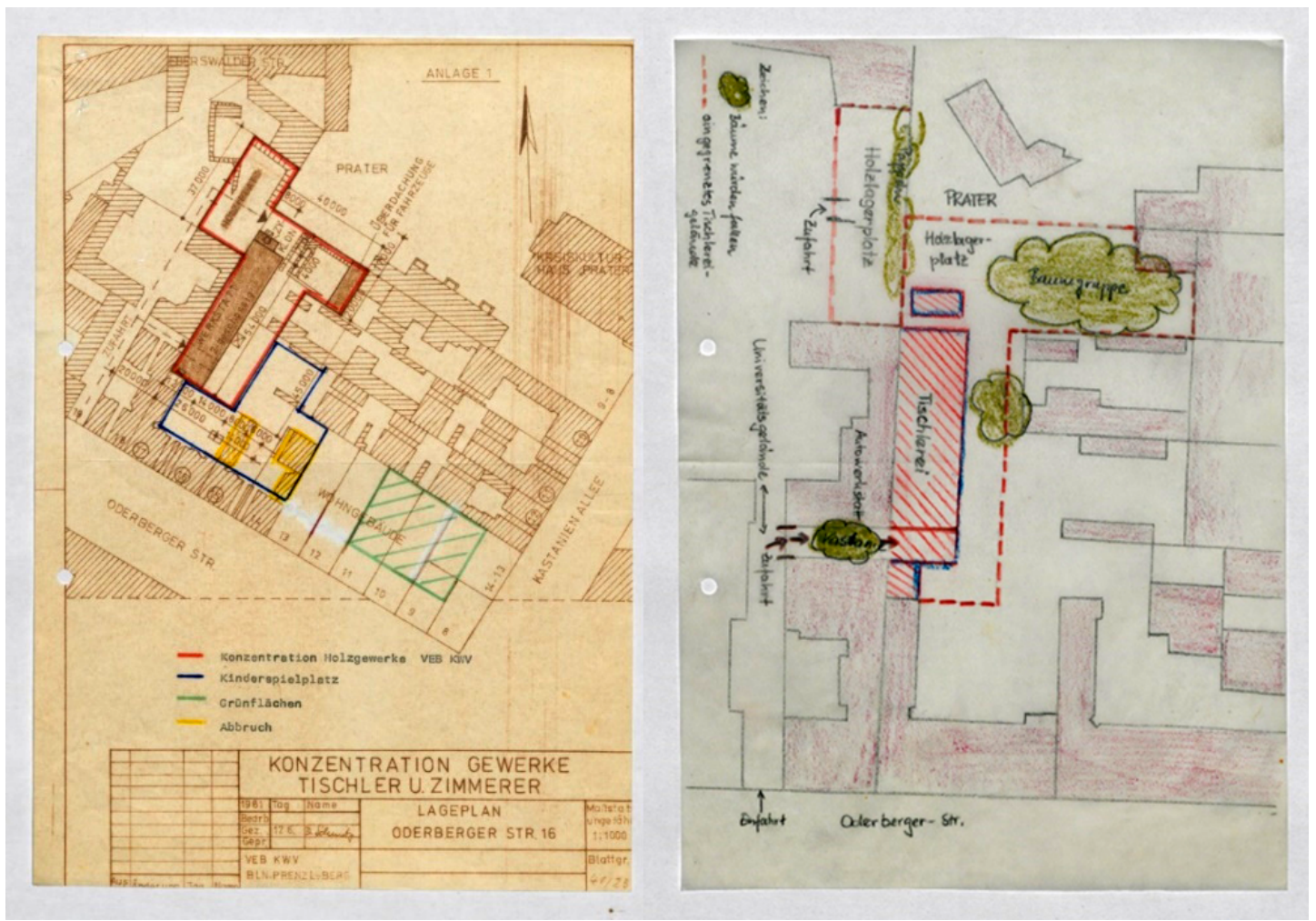

Figure 1. From left to right: Maps for the backyard conversion designed by planning authorities and neighbourhood actors. Sources: "Städtebauliche Bestätigung (Reg.-Nr. 204/81)" (1981). Image rights: Landesarchiv Berlin. 


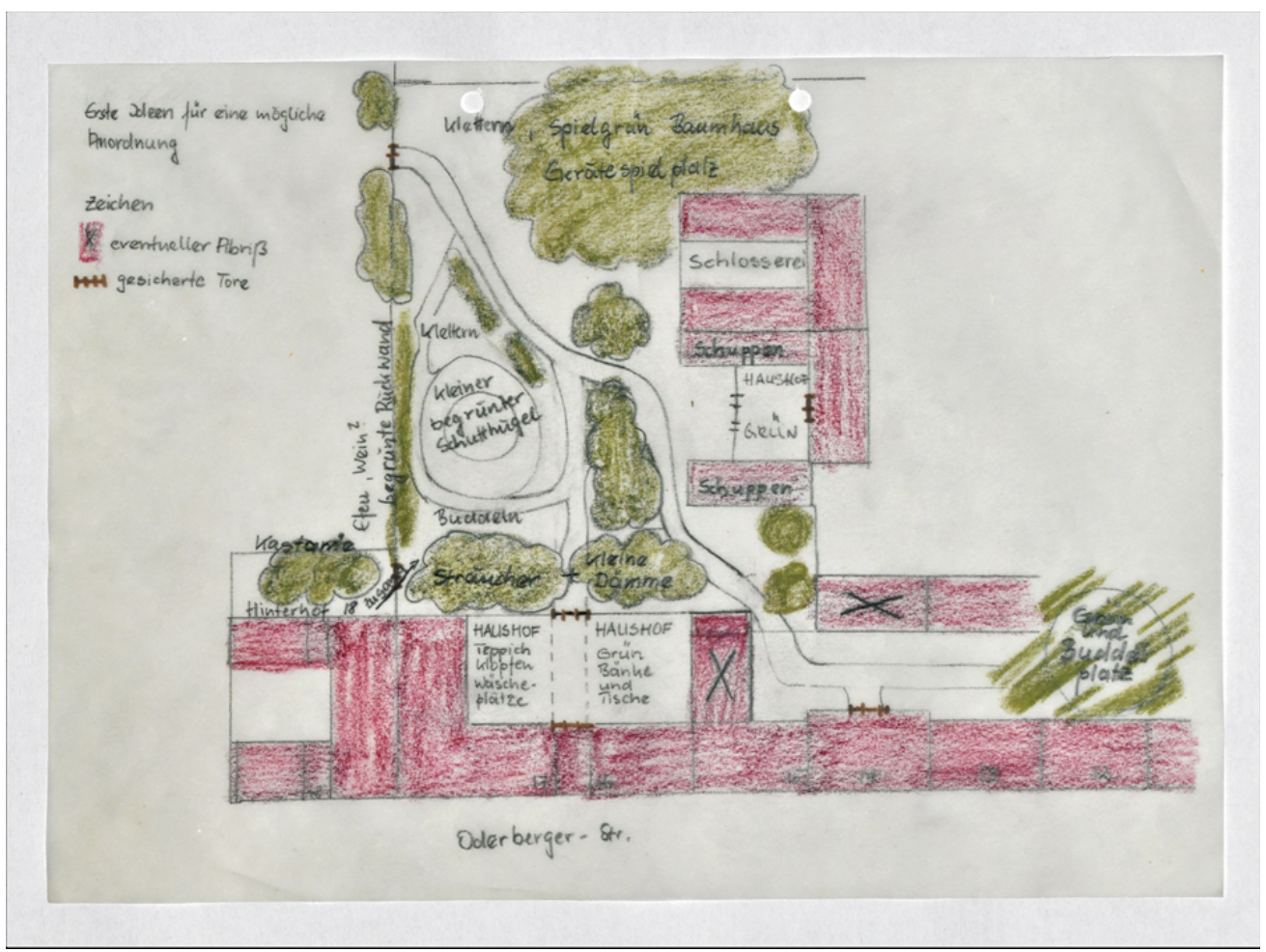

Figure 2. Draft of the conversion map drawn by the neighbourhood initiative of Oderberger Street 15/17. Source: "Eingabe zum Bauvorhaben Tischlerei/Kinderspielplatz auf dem Gelände hinter den Häusern der Oderberger Str. 15-18” (1981). Image rights: Landesarchiv Berlin.

two on-site visits and several face-to-face talks. However, 'public' meant that only a few selected neighbourhood representatives could attend as these communication meetings. Following the socialist understanding of public negotiation, key figures on both sides functioned as district municipality officers or as appointed representatives of civic society. Although the civic influence on decision-making practices related to the planning aspects of the project seem limited, archive documents reveal their impact on local politics. In district council meetings, political and planning authorities regularly analysed and reflected upon the active and critical contributions of neighbourhood representatives in assemblies and permanent submission letters. Several suggestions were ultimately implemented into the formal planning concept and the monthly or annual quota achievement documents (Haushalts- und Volkswirtschaftsplan) of the district municipality. Due to staff and resource shortages in Prenzlauer Berg and the housing boroughs of Oderberger Street, several planned communicative interactions remained unrealised. Nevertheless, in December 1981, the council adopted a resolution that shifted the location for the workshops and conceded to a joint conversion plan. Its contents conveyed the construction of a playground and of a more expansive green space as a cooperation between planning authorities and the neighbourhood initiative (Council of the BerlinPrenzlauer Berg District, 1982).

Between 1982 and 1984 neighbourhood initiatives, which were formally affiliated with representatives in the housing borough committee, fulfilled the project with district council support (in the form of material, financial and advisory resources). Although the project was based on a bottom-up civic initiative, an extraordinary endeavour for its time, which was made possible due to the broad, fervent civic involvement in the planning process, political authorities credited the successful conversion for its planning propaganda. The initially so reluctant acting district municipality instrumentalised the courtyard, which, in the following years, became a famous cultural hub in East Berlin, for the growing popularity of green space conversions. The general need for green spaces within the dense and decaying housing districts and the increasing economy of scarcity is reflected in the GDR planning culture in mid-1980s (Topfstedt, 1999). While the deterioration of economic power and political sovereignty became more visible-for citizens as well as for the 'capitalist opponents' behind the Iron Curtain - the demonstration of power and control during this period in the GDR was important. Thus, the greening trends were implemented and propagated more prominently in the Mach Mit campaigns. This strategy killed two birds with one stone: First, it improved living conditions by masking economic limitations while demonstrating state control, and second, it sought to lower discontent through the promotion of civic engagement and buttress state support. As such, the discussed case was portrayed as success story and shaped the official narrative for a pioneering-grassroots urban renewal ("Leaflet documents," 1984). 


\section{Public Dialogue and Participation Arrangements in the 1980s West Berlin Planning Culture}

The early 1970s witnessed the dawn of a new era in planning culture, which was largely influenced by AngloAmerican paradigms (Bolan, 1969; Schubert, 2017; Wakeman, 2014). The period saw a kind of democratisation of its planning practice as communication with the public became a more crucial, legitimating element of local municipalities and their proposed projects. Over time, a steady shift took place from the original comprehensive paradigm in which single planners oversaw large-scale projects to a cooperative project-based decision-making process that used new communicative instruments to include a variety of actors and interests (Haumann, 2015). Based on the democratic understanding of the FRG, an 'open' society shall consider individual as well as collective interests in a (critical) public dialogue. According to urban renewal principles the negotiation process of planning had to include active civic participation, which was also fixed in the legal regime; for instance in the Law for the Promotion of Urban Renewal (Städtebauförderungsgesetz, 1971) and the Federal Town Planning Law (Bundesbaugesetz, 1976). In West Berlin, planning practice encountered urban renewal by various small-scale projects in large redevelopment areas. The 1980s culminated in the general pluralisation of society, which was accompanied by political upheaval, widespread frustration and population decrease (Jarausch, 2008). The municipality of West Berlin responded to both the decaying inner-city housing structures and critiques regarding planning politics with the Second Urban Renewal Programme (Senator für Bau- und Wohnungswesen, 1974), the International Planning Exhibition (IBA; Senator für Bau- und Wohnungswesen Berlin, 1978) and the 12 Guidelines of Urban Renewal (Hämer, 1984). Pioneering projects such as at Klausener Platz combined urban renewal with the testing of new communicative instruments in planning practice to increase local civic participation. Following the implementation of participatory planning as the common practice, visualisations were used as independent instruments evermore. The strategic impetus sought to promote and facilitate multilateral public communications within the process of negotiating a planning consensus (Freestone, 2015; Reuß, 2013). Here, the complexity of planning situations was supposed to be made comprehensible for all-regardless of planning knowledge/expertise-via the use of visual instruments, such as collages, illustrations, drafts, schemes, models and photographs (Schultz \& Stein, 2013). On a city-wide and national level, successful pilots reportedly generated broad public acceptance and legitimisation for the planning paradigm and its political implementation (see Figure 3).

The second case, Bülowstraße, block 86-89, illustrates a pilot project of environmental sustainability in urban renewal. In 1986, it was declared as the last project of the redevelopment area in the district of Schöneberg (see Figure 4). Here, the agenda sought to modernise the historic housing structure and improve living conditions through the reduction of urban density, the establishment of greening measures and sustainable energy consumption and the guarantee that the existing population could remain at no additional charge.

Adapting the prior mentioned legal planning regulations in designated areas, a comprehensible and citizen-
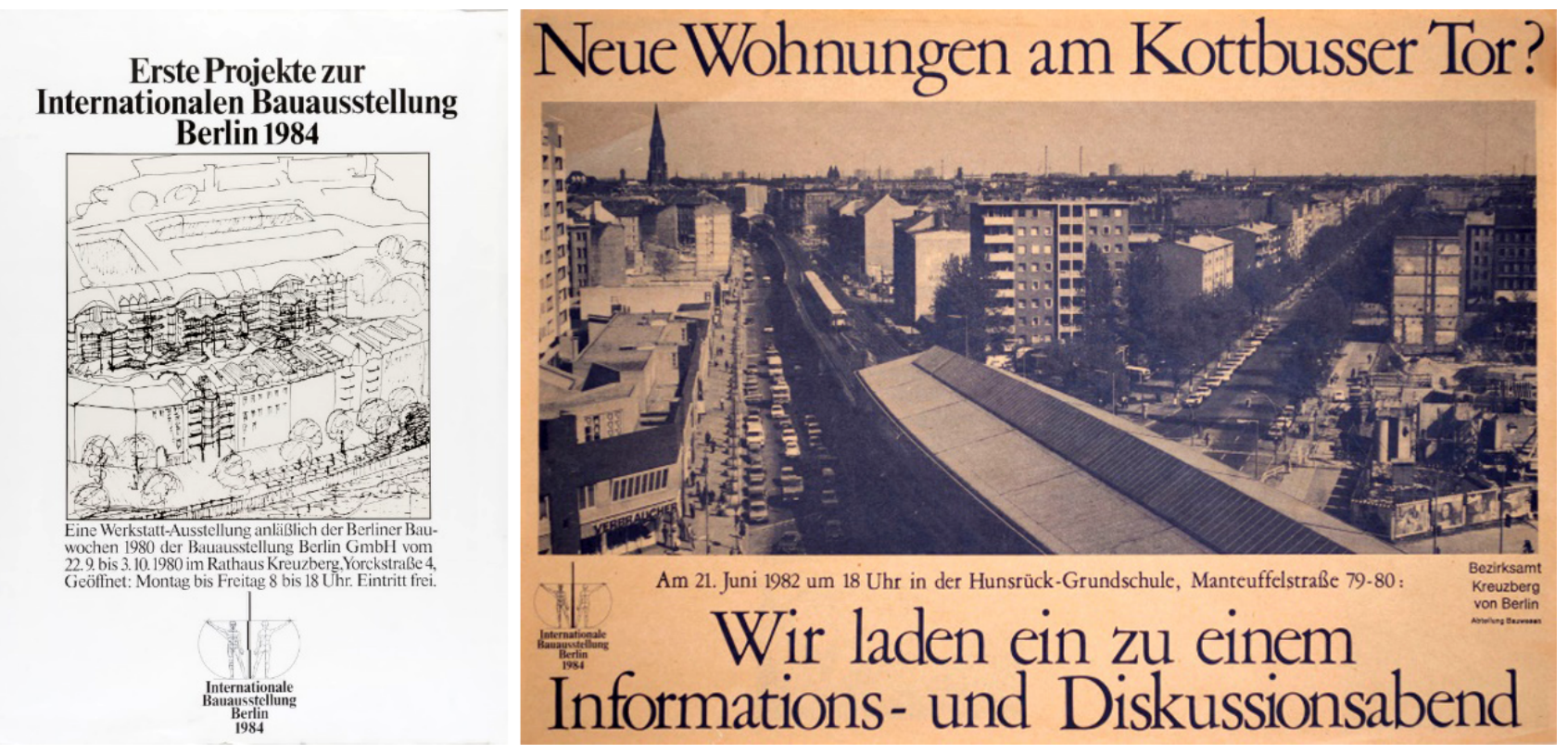

Figure 3. From left to right: Posters of the international planning exhibition in Kreuzberg inviting the public to a workshop exhibition in 1980 and an assembly in 1982. Sources: "First Projects for the International Building Exhibition Berlin 1984" (1980) and "New apartments at Kottbusser Tor?" (1982). Image rights: S.T.E.R.N. Gesellschaft der behutsamen Stadterneuerung $\mathrm{mbH}$. 

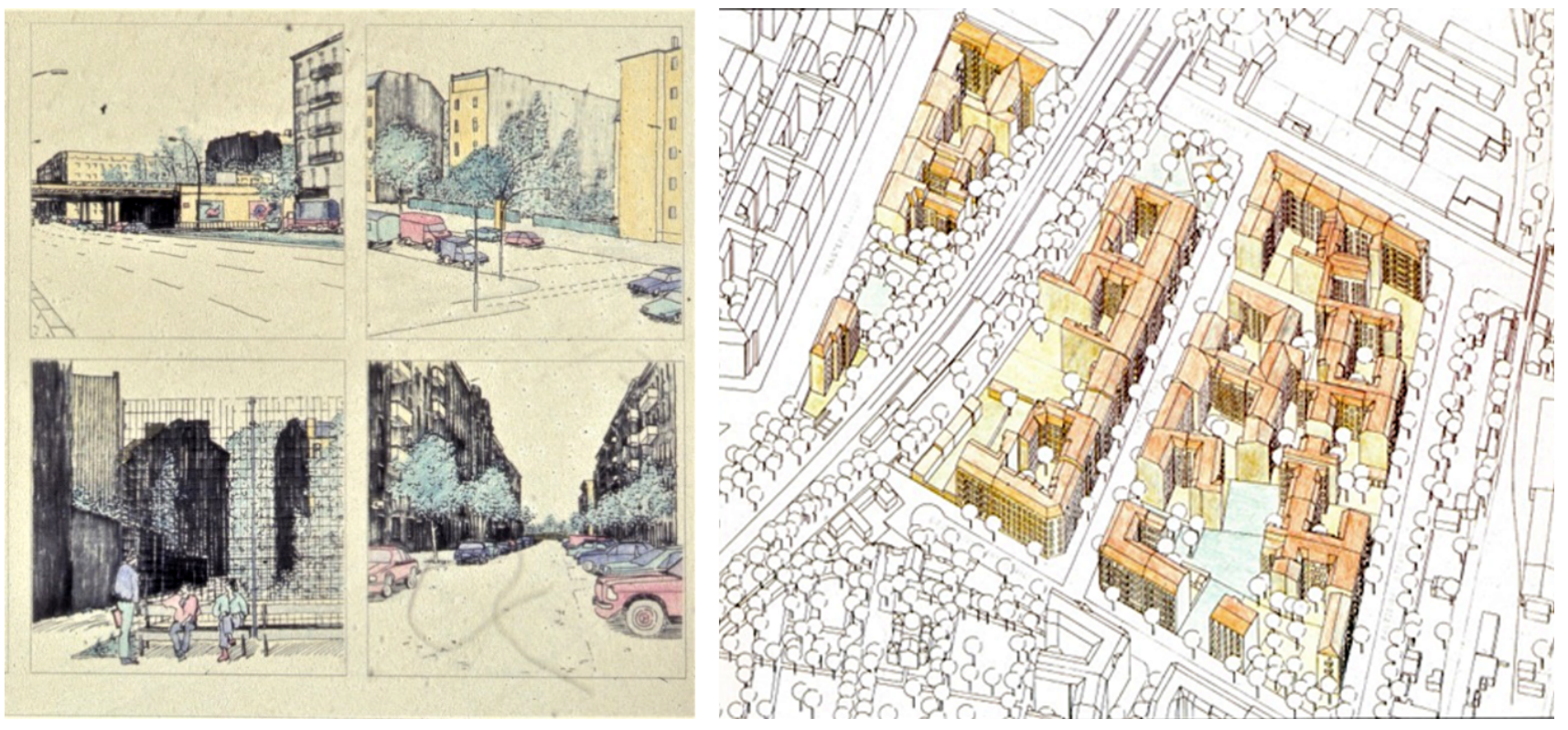

Figure 4. From left to right: Visualisations illustrating a vision of the redevelopment area after the implementation to facilitate the public dialogue and negotiation process and a sketch explaining the demolition plans to clear space and improve living conditions. Source from left to right: Planergemeinschaft Kohlbrenner \& Dubach (1989); Bezirksamt Schöneberg (1992). Image rights: Planergemeinschaft Stadt und Raum eG.

oriented communication strategy was launched before the start of renewal work. This strategy entailed the planning authorities informing those to be affected by the proposed project through public announcements, displays, and arranging setup opportunities for Q\&As in order to facilitate feedback. Finally, a public assembly to encourage a dialogue between the planners involved with the project and affected residents was initiated. According to stated procedure, comments and critique were to be verified by the planning authorities and, if relevant, were required to be integrated into the planning concept. Afterwards, public announcements concerning the revised project had to be displayed once more-for the public's consideration, so they could invoice any potential feedback. While this procedure followed democratic and participatory principles, it also bore the risk of prolonging the preparation process. Consequences that such extensions could have for the implementation of the planning project will be examined later.

The responsibility of the whole project fell to the district municipality of Schöneberg, which delegated several tasks to non-corporate planning offices and several district offices. Although the planning authorities built on successfully implemented projects from earlier years, the individual context of each planning area presented a new challenge every time. Here, it was to integrate both the many new planning goals (related to sustainable and urban renewal) as well as citizen-oriented communication and participation strategy. A local office was installed in the project's neighbourhood by an independent consulting agency (Arbeitsgemeinschaft für Sozialplanung und angewandte Stadtforschung [AG SPAS]), which served as a permanent direct contact and service point with experts in planning, sociology and education (Bezirksamt Schöneberg, 1991). In this case, the institution functioned as a transmitter between political authorities and residents. More specifically, the office operated as a translator of planning issues to the public as well as a consultant that supported tenants in matters of ecological issues. Additionally, also it functioned as a data collector and observer of existing circumstances within the district municipality and planning offices as well as a moderator of social and financial aspects caused by renewal consequences. Their communication strategies included individual face-to-face interactions, public assemblies as well as media campaigns (see Figure 5).

In these various versions of communication visualisations took an important role, which will be examined in detail in a moment. Concrete aspects of ecological renewal, including energy-saving measures and sustainable living in everyday life or the advantages of greened facades, were articulated either in smaller face-to-face consultations, information sessions or via information brochures. In the brochures, visual elements, such as photos, models and illustrations, were accompanied by spoken or written information (see Figure 6). Assemblies and information meetings regarding the planning project and any of the latest process adaptions were proceeded in a similar manner; that is through face-to-face encounters in information documents. Here, the archival documents reveal that the written documents were bilingual (German and Turkish) due to the social structure of the neighbourhood. In its function as a data collector, the staff of the consulting agency, AG SPAS, not only gathered information, such as statistics, but they also con- 


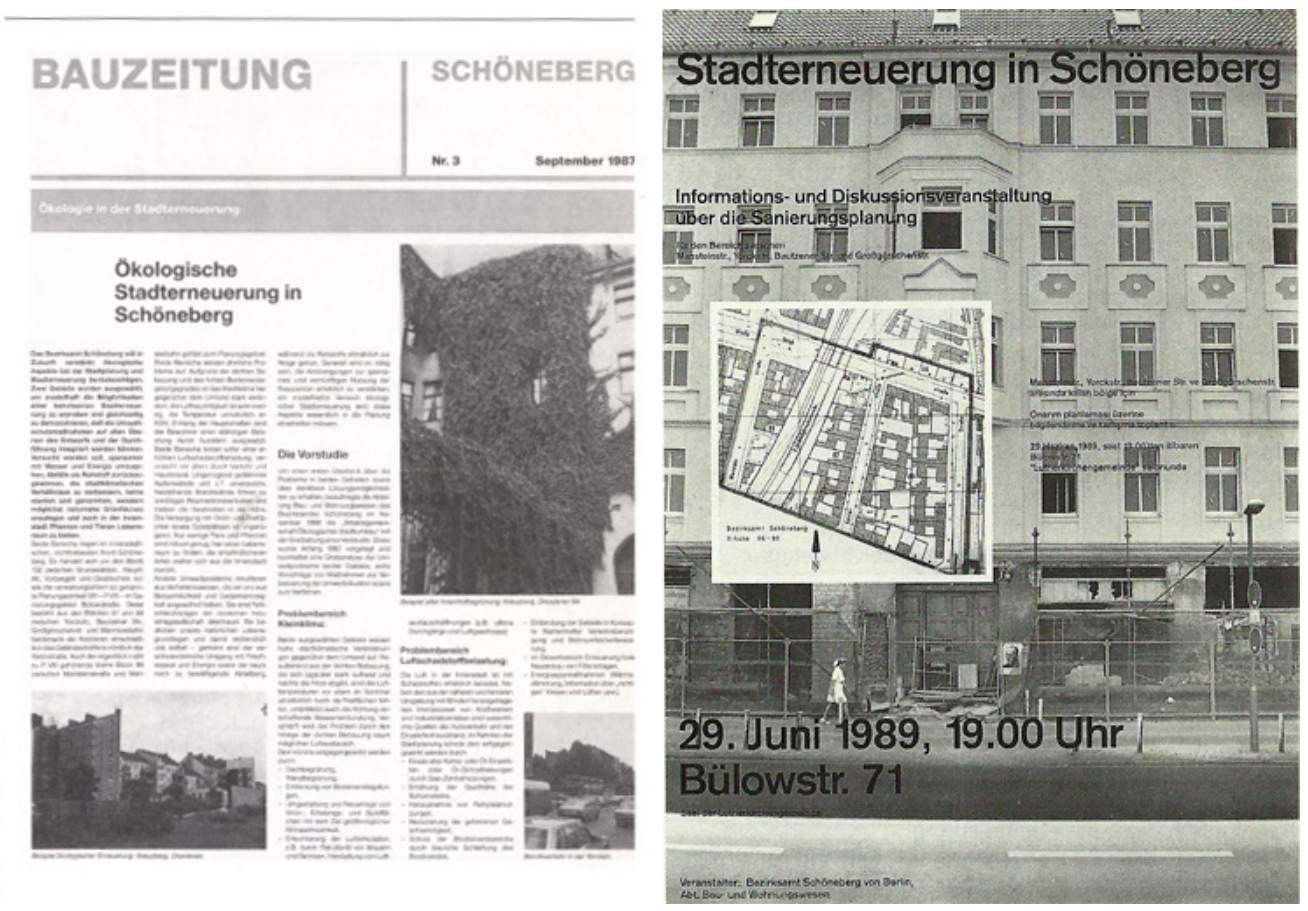

Figure 5. From left to right: Newspaper article about sustainable urban renewal within the redevelopment area and invitation leaflet for the second consideration meeting. Source: Bezirksamt Schöneberg (1992).

ducted surveys through sending questionnaires, which were distributed to the households as well as on-site visits with inhabitants. Within this particular format of public communication, visualisations did not play a significant role. As such, data reports for the planning and political authorities were shaped more by planners' vocabu- lary and less by visual elements, aside from data statistics and graphics.

Before analysing the essential communicative tool of inhabitant representation (Betroffenenvertretung), it is important to consider the social structure of the affected neighbourhoods. The social composition was pri-
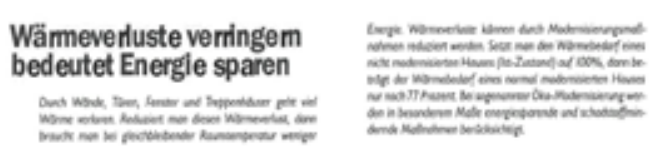

Einsparungseffekte durch Wärmedämmaßnahmen
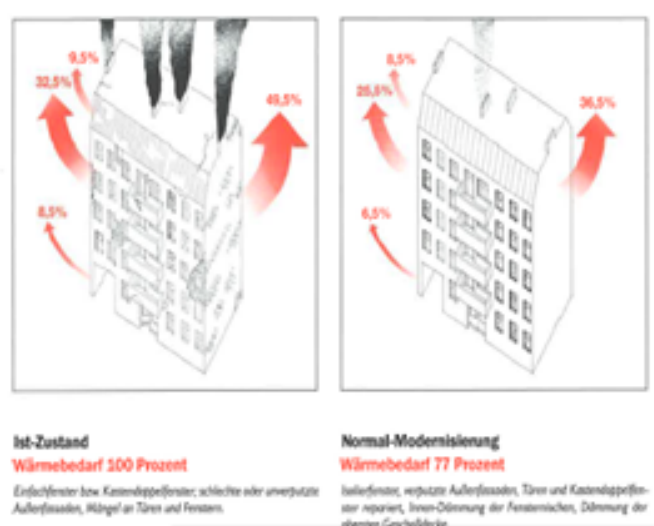

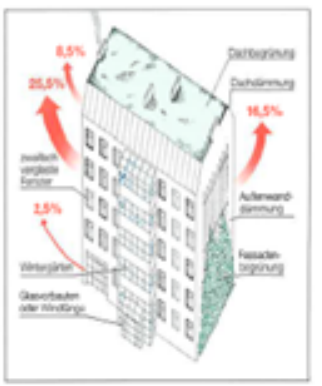

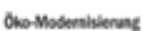

Wirmedentidenang

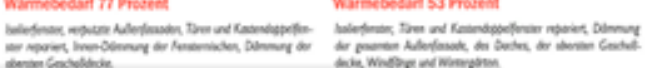

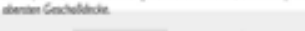

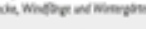

Figure 6. Information leaflet explaining cost savings through the sustainable urban renewal measurements. Source: Source: Bezirksamt Schöneberg (1992). Image rights: ÖKOLAUS-Ökologische Landschaftspflege, Architektur und Siedlungsplanung and AG SPAS. 
marily characterised by low-income and low-education level, Turkish migrants and large families (Bezirksamt Schöneberg, 1992, pp. 48-50). With regard to the inhabitant representation, population demographics were a vital element in the case of Bülowstraße, block 86-89. Formally required in 1977 for redevelopment areas, elected representatives of the affected community could attend meetings between planning authorities and related actors, which allowed them to participate directly in the negotiation and decision-making process. In this case, a permanent engagement of representatives could not be arranged because the public's focus was spread across numerous individual topics and the complexity of the whole project expected too much. Consequently, because no elected inhabitant representation came into existence, by law every affected person could attend the round tables. Archival sources reveal a heavily reliance on technical language-spoken only in German-at the meetings, which made them difficult to follow for laypeople. Hence, a structured public negotiation process including active civic participation existed just temporary and topic based.

Furthermore, the implementation of the project took longer than expected due to the complex, interdepending planning issues and the multitude of institutions involved. Additionally, the slow diminishment in funding led to fewer expenditures in the public communication strategy and employment of staff in the local office. The consulting agency AG SPAS tried to compensate the shortened expenses for direct and local communication by media campaigns such as information documents. This prolonged period of setbacks gave rise to uncertainty and doubts amongst residents who had grown sceptical of the project and its promises, of lease stability, protection from displacement and sustainable renewal. The complexity of the project and the lengthy duration of the whole process ultimately led to decreased interest in public participation.

Nevertheless, the project was realised between 1990-1992. All inhabitants, who wished to return, were provided with housing at no additional expense. Although there had been a lack of interest and scepticism about the innovative approach of environmental sustainability, inhabitants were satisfied with the final results (Bezirksamt Schöneberg, 1992, pp. 48-50). The planning authorities, who failed to implement the entirety of their communication strategy, reflected on their pioneering project and were able to draw conclusions on how to improve their approach on future planning projects. In the end, the political and planning authorities perceived the case of Bülowstraße, block 86-89, as a successful implementation.

\section{Conclusion}

This article examined the crucial role that innovative strategies of communication and visualisation were playing during the changing culture of urban planning that emerged in the 1970s and 1980s. In order to better understand the historical context of this process, a longterm perspective was applied to our case studies in East and West Berlin, which exemplify variations in strategy and effect in both the socialist and capitalist societies on either side of the Wall during the Cold War. Despite the unique challenges Berlin faced related to the destruction it suffered during the war and its affliction with stagnated urban development, the city rose from its embers in the decades that followed where it became fertile ground for competing ideologically driven urban planning projects. Large-scale projects for housing and motorways were presented in expansive public campaigns, which were promoted using visual instruments, such as international building exhibitions, large competitions or regional plans. While different institutional systems prevailed on both sides, often amidst intense political confrontation, both systems followed similar concepts of top-down planning and prioritised the construction of buildings for the development of the national capital or a centre of culture.

The article highlighted the fundamental shift in planning culture from one marked by its political antagonism to one that was less hostile over the course of the 1970s. Within these changing circumstances, both sides and their opposing political agendas began developing innovative strategies for urban renewal of the historic inner-city. The shift to small-scale planning and the more significant involvement of citizens and their interests led to the adoption of new approaches, which empowered local actors involved in political administration and planning. Furthermore, adaptation of the planning culture further broadened the field of responsible actors. While larger decision-making processes were typically mediated in higher state institutions, where they were strongly shaped by their respective ideological frameworks, planners typically managed day-to-day operations, including the administration of public communication.

Using two small-scale cases, the article empirically demonstrated the ways in which unique, individual contexts impacted the management and operation of planning projects. Reflecting on the use of communicative instruments and visual tools between city planners and residents, it became clear that public communication merges the political frame and formal planning guidelines with the concrete local conditions, including social structure, planning ambition and level of urban identity (Häußermann \& Siebel, 2004; Selle, 2017), through the planner's customised "toolkit" (Freestone, 2018, p. 199). The use of particular visual and communicative instruments is dependent on the involved actors who produce and send messages and thereby produce a public. The East Berlin case demonstrated how a strong sense of urban identity combined with a permanent as well as clever use of regular communication strategies could strengthen civic engagement. A bottom-up approachmarked by its profound use of visualisations-initiated public communication, which later became an influential voice during the negotiation process of the courtyard 
conversion. By contrast, the West Berlin case stressed the importance of altering communicative strategies to the local context. In this case, even though formalised planning preconditions offered structures to facilitate a broad dialogue between the public and planners, blind spots regarding the demographic structure of the neighbourhood in question and an incomplete reflection concerning the residents' willingness to participate in the planning process, has challenged the success (of practice rather than final acceptance) of the project.

The ambivalence of planning culture was also examined; that is, the tension between using urban planning as a function of the political imagination or as an "image of the future" (Seehausen, 2015, p. 117), and the challenges related to the practical implementation of such visions. The variety of deployed media, communication instruments and visual tools reflects the degree of social differentiation and the necessity of adapting the planner's "toolkit" as it pertains to specific topics, language, regulations and resources as well as involved actor groups, 'sending,' 'perceiving' and voice claiming actor constellations. With regard to the role of visualisations as communicative tools in planning discourses, it became clear that while visuality was treated as a device that could speak for itself in planning theory, in practice it was often used to support, accompany or illustrate written and spoken topics. Undoubtedly, visualisations appealed to audiences that were being addressed and helped promote a dialogue between the actor groups. The variety of used visualisations highlights the many creative ways this tool was deployed during the negotiation process of planning projects, which both cases demonstrate within the context of their own political systems and planning cultures.

Through the investigation of urban planning practices and their relationship to the public within the distinct political systems of East and West Berlin, two similarities can be located: One, in both micro-scale cases, major ideological concepts in social and political discourses that emanated from higher government structures were reproduced in planning processes and projects, which can be observed in forging a public dialogue and the development of the concept of urban renewal. Two, the pioneering role of the urban renewal projects that were analysed shaped subsequent projects as well as today's planning culture, more generally. With both projects, innovative communicative strategies were tested and ultimately paved the way for future planning projects and present-day paradigms related to multilateral digitised communication, civic participation in planning discourses beyond formally declared development areas, bottom-up decision-making and citizen-oriented urban sociology.

\section{Acknowledgments}

With great thanks to Mariana Pires and the issue's editors Jörg Stollmann and Gabriela Christmann for pro- viding their editorial support on short notice, and to Kathleen V. Gilliland for proofreading our text. We are indebted and grateful to the broader project team, Ajit Singh and Mennatullah Hendawy, for their contributions and collaborative spirit in developing the intellectual frameworks of the broader project. Thanks also go to Rebecca Roggisch and Petra Geral for their constant support. We are thankful for the authorisation of image rights from AG SPAS, FHXB Friedrichshain-Kreuzberg Museum, Landesarchiv Berlin, ÖKOLAUS-Ökologische Landschaftspflege, Architektur und Siedlungsplanung, Planergemeinschaft für Stadt und Raum eG, and S.T.E.R.N. Gesellschaft der behutsamen Stadterneuerung $\mathrm{mbH}$. The research in this contribution is part of the project "Mediatisation Processes in Urban Design and Planning: Changes to the Public Sphere" (MedPlan, 2017-2020) funded by the Leibniz Competition Programme of the Leibniz Association under the project number J68/2016.

\section{Conflict of Interests}

The authors declare no conflict of interests.

\section{References}

Albers, G. (2006). Zur Entwicklung des Planungsverständnisses. Kontinuität und Wandel [About developments in understanding planning. Continuities and changes]. In K. Selle (Ed.), Planung neu denken. Part 1: Zur räumlichen Entwicklung beitragen. Konzepte. Theorien. Impulse [Re-thinking planning. Part 1: Participating spatial development. Concepts. Theories. Incentives] (pp. 43-55). Dortmund: Rohn.

Barclay, D. A. (2012). A 'complicated contrivance.' West Berlin behind the Wall, 1971-1989. In M. Silberman, K. E. Till, \& J. Ward (Eds.), Walls, bounders, boundaries. Spatial and cultural practices in Europe (pp. 113-130). New York, NY: Berghahn.

Bernhardt, C. (2020). Planungen für den Großraum Berlin in den Jahrzehnten der geteilten Stadt [Planning the metropolitan area Greater Berlin during divided city decades]. In H. Bodenschatz \& H. Kegler (Eds.), 100 Jahre Groß-Berlin: Planungskultur und Stadtentwicklung [100 year jubilee of Greater Berlin: Planning culture and urban development] (pp. 120-143). Berlin: Lukas Verlag.

Betker, F., \& Bräuer, M. (2006). Stadtplanung als öffentliche Angelegenheit. Kontinuität und Wandel des Planungsverständnisses in Ostdeutschland [Urban planning as a public matter. Continuity and change in understanding planning in East Germany]. In K. Selle (Ed.), Planung neu denken. Part 1: Zur räumlichen Entwicklung beitragen. Konzepte. Theorien. Impulse [Re-thinking planning. Part 1: Participating spatial development. Concepts. Theories. Incentives] (pp. 85-102). Dortmund: Rohn.

Bezirksamt Schöneberg. (Eds.). (1991). Stadterneuerung 
im Sanierungsgebiet Schöneberg-Bülowstraße, Blöcke 86-89: Ökologisch orientierte Stadterneuerung [Urban renewal in the urban development area Schöneberg-Bülowstraße, blocks 86-89]. Berlin: Senatsverwaltung Berlin.

Bezirksamt Schöneberg. (Eds.). (1992). Ökologisch orientierte Stadterneuerung in Berlin: Ein Projekt des Bezirksamtes Schöneberg von Berlin. Berlin baut 11 [Environmental urban renewal in Berlin: A project by the municipal district Schöneberg, Berlin]. Berlin: Senatsverwaltung Berlin.

Bodenschatz, H., \& Kress, C. (Eds.). (2017). Kult und Krise des großen Plans im Städtebau [Cult and crisis of the great plans in town planning]. Petersberg: Michael Imhof Verlag.

Bolan, R. (1969). Community decision behavior: The culture of planning. Journal of the American Institute of Planners, 35(5), 301-310.

Bundesbaugesetz [Federal town planning law]. (1976). Bundesgesetzblatt, 105, 2257-2317.

Council of the Berlin-Prenzlauer Berg District. (1982, January 28). Beschlussvorlage Eingabenanalyse 2. Halbjahr 1981. [Submission analysis]. Rat des Stadtbezirks Prenzlauer Berg, Ratssitzungen (C Rep. 134-02-02 1249). Landesarchiv Berlin, Germany.

Eingabe zum Bauvorhaben Tischlerei/Kinderspielplatz auf dem Gelände hinter den Häusern der Oderberger Str. 15-18. (1981, October 8). [Submission Document]. Magistrat von Berlin, Oberbürgermeister (C Rep. 101 1863). Landesarchiv Berlin, Germany.

Engler, H. (2012). Das institutionelle System des DDRBauwesens und die Reformdebatte um den Städtebau in den 1980er Jahren [The institutional system of GDR construction industry and reform debates on town planning during the 1980s]. In C. Bernhardt, T. Flierl, \& M. Welch Guerra (Eds.), Städtebau-Debatten in der DDR. Verborgene Reformdiskurse [Town planning debates in the GDR. Hidden reform discourses] (pp. 71-104). Berlin: Theater der Zeit.

First Projects for the International Building Exhibition Berlin 1984. (1980). [Poster]. Urban Renewal and Social Movements in Kreuzberg, 1970 to 1990 (2015/3510). FHXB Friedrichshain-Kreuzberg Museum, Berlin, Germany. Retrieved from https:// berlin.museum-digital.de/index.php?t=objekt\&oges $=7459 \&$ cachesLoaded $=$ true

Freestone, R. (2015). The exhibition as a lens for planning history. Planning Perspectives, 30(3), 433-446.

Freestone, R. (2018). Visualising the emergence of a new profession in New York, Berlin and London 1909-1910. In K. F. Fischer \& U. Altrock (Eds.), Windows upon planning history (pp. 187-202). New York, NY: Routledge.

Geist, J. F., \& Kürvers, K. (1989). Das Berliner Mietshaus 1945-1989 [The Berlin tenement block]. Munich: Prestel.

Habitat DDR. (1976). Gesellschaftspolitische und ökonomische Grundlagen, Wohnungsbau, Städte- bau und Siedlungsnetzplanung in der Deutschen Demokratischen Republik [Socio-political economic basics, housing construction, town planning and planning of settlement infrastructures in GDR]. Berlin: Ministerium für Bauwesen der Deutschen Demokratischen Republik.

Hämer, H. W. (1990). Behutsame Stadterneuerung [Urban renewal]. In Stadterneuerung Berlin [Urban renewal in Berlin]. Berlin: Senatsverwaltung Berlin.

Haumann, S. (2015). Protest und Wertewandel. Zur Dynamik von Planungskulturen in den 1970er Jahren [Protests and shifting values. Dynamics of planning cultures during the 1970s]. In F. Othengrafen \& M. Sondermann (Eds.), Städtische Planungskulturen im Spiegel von Konflikten, Protesten und Initiativen [Urban planning cultures reflected in conflicts, protests and initiatives] (pp. 95-110). Berlin: Verlag Uwe Altrock.

Hauser, S. (2018). Signs and symbols in planning processes (1975-1995). In K. F. Fischer \& U. Altrock (Eds.), Windows upon planning history (pp. 231-246). New York, NY: Routledge.

Häußermann, H., \& Siebel, W. (2004). Stadtsoziologie: Eine Einführung [Urban Sociology. An introduction]. Frankfurt: Campus-Verlag.

Healey, P. (1992). Planning through debate: The communicative turn in planning theory. The Town Planning Review, 62(2), 143-162.

Hoffmann-Axthelm, D. (2000). Ortsverschiebung- die 60er Jahre: Zentrumsplanung in Ost und West [Spatial shifts during the 1960s. City centre planning in East and West]. In T. Scheer, J. P. Kleihues, \& P. Kahlfeldt (Eds.), Stadt der Architektur der Stadt. Berlin 1900-2000 [City of architecture of city. Berlin 1900-2000] (pp. 295-306). Berlin: Nicolai.

Jacobs, J. (1961). The death and life of great American cities. New York, NY: Vintage Books.

Jarausch, H. (Ed.). (2008). Das Ende der Zuversicht? Die siebziger Jahre als Geschichte [The end of confidence? The 1970s as history]. Göttingen: Vandenhoeck Ruprecht.

Klemek, C. (2011). The transatlantic collapse of urban renewal. Post-war urbanism from New York to Berlin. Chicago, IL: The University of Chicago Press.

Kress, C. (2014). Anker oder Ärgernis. Die Berliner Kaiser-Wilhelm-Gedächtniskirche zwischen Wiederaufbaustreit und Urban Icon [Entrenchment or offence. Kaiser Wilhelm Memorial Church in Berlin in debates between reconstruction and urban icon]. In G. Wagner-Kyora (Ed.), Wiederaufbau europäischer Städte. Rekonstruktionen, die Moderne und die lokale Identitätspolitik seit 1945 [Rebuilding European cities. Reconstructions, modernity and the local politics of identity construction since 1945] (pp. 349-366). Stuttgart: Franz Steiner Verlag. vKrotz, F. (2007). Mediatisierung: Fallstudien zum Wandel von Kommunikation [Mediatisation: Cases of transforming communication]. Wiesbaden: Springer. 
Leaflet documents. (1984). [Collection of several leaflet documents]. Nachlass B. Holtfreter, Unterlagen von Bernd Holtfreter zu seiner Tätigkeit als WBAVorsitzender (BHo 15, WBA 56, 1984-1994). RobertHavemann-Gesellschaft, Archiv der DDR-Opposition, Berlin, Germany.

Lee, M. K., \& Weiß, S. (2019). Introduction: Cities on paper: On the materiality of paper in urban planning. Journal of Urban History, 46(2), 239-247.

Mitscherlich, A. (1965). Die Unwirtlichkeit unserer Städte [The inhospitality of our cities]. Frankfurt: Suhrkamp Verlag.

Mook, V. (2013). Visualisierung: Planung sichtbar machen [Visualisations. Making planning visible]. PlanerIn, 2013(1), 3-4.

Mühlberg, F. (2004). Bürger, Bitten und Behörden. Geschichte der Eingabe in der DDR [Citizens, inquiries and public authorities. The history of submissions in GDR]. Berlin: Dietz Verlag.

New apartments at Kottbusser Tor? (1982). [Poster]. Urban Renewal and Social Movements in Kreuzberg, 1970 to 1990 (2015/3547). FHXB FriedrichshainKreuzberg Museum, Berlin, Germany. Retrieved from https://berlin.museum-digital.de/index.php? $\mathrm{t}=$ objekt\&oges=7599\&cachesLoaded=true

Planergemeinschaft Kohlbrenner \& Dubach. (1989). Städtebauliches Konzept für die Blöcke 86-89 im Sanierungsgebiet Berlin-Schöneberg P VI und P VIII [Town planning concept for the resident blocks 86-89 within the redevelopment area of Berlin Schöneberg $\mathrm{P} \mathrm{VI}$ and $\mathrm{P} \mathrm{VIII}$. [Planning documents]. Internal archives of Planergemeinschaft Stadt und Raum eG, Berlin, Germany.

Pollack, D., \& Rink, D. (Eds.). (1997). Zwischen Verweigerung und Opposition: Politischer Protest in der DDR 1970-1989 [Amongst refusal and opposition: Political protest in the GDR 1970-1989]. Frankfurt and New York, NY: Campus-Verlag.

Reuß, A. (2013). Visualisierung und Bürgerbeteiligung: Zwischen Handskizze und 3D-Film- das Beispiel Rahmenplan Bad Waldsee [Visualisations and civic participation. Amongst manual drawings and 3D movies]. Planerln, 2013(1), 11-13.

Schubert, D. (2017). Opposition, participation, and community-driven planning histories. In C. Hein (Ed.), Routledge handbook of planning history (pp. 338-349). New York, NY: Routledge.

Schubert, D. (Ed.). (2014). Contemporary perspectives on Jane Jacobs. Reassessing the impacts of an urban visionary. Farnham: Ashgate.

Schultz, H., \& Stein, U. (2013). Bilder in kommunikativen Entwurfsprozessen [Images in communicative design processes]. Planerln, 2013(1), 23-25.

Seehausen, F. (2015). Schwungvoll in die Zukunft: Die Inszenierung des fließenden Verkehrs im Berlin der 1960er Jahre [Dynamics for the future. Staging moving traffic in Berlin during the 1960s]. In K. Wittmann-Englert (Ed.), Radikal Modern. Planen und
Bauen im Berlin der 1960er Jahre [Radically modern. Planning and constructing Berlin during the 1960s] (pp. 114-123). Tübingen and Berlin: Ernst Wasmuth Verlag.

Selle, K. (1996). Planung und Kommunikation [Planning and communicaton]. In K. Selle (Ed.), Planung und Kommunikation. Gestaltung von Planungsprozessen in Quartier, Stadt und Landschaft: Grundlagen, Methoden, Praxiserfahrungen [Planning and communication. Designing planning of neighbourhoods, cites and landscapes: Basics, methods, practical experience] (pp. 11-20). Wiesbaden: Bauverlag.

Selle, K. (2017). Kommunikative Interdependenzgestaltung in Prozessen der Stadtentwicklung: Eine Geschichte der Entdeckungen. Teil 2: Wendepunkte. Paradigmenwechsel in der Theorie eröffnen neue Perspektiven auf die Praxis [Communicative interdependences in urban development processes. A history of discoveries. Part 2: Turning points and paradigmatic shifts in theory enable new perspectives for practical implementations]. pnd/online, 2013(1), 1-18.

Senator für Bau- und Wohnungswesen. (Eds.). (1974). Bericht über Stadterneuerung 1.1.-31.12.1973. Mitteilungen des Präsidenten des Abgeordnetenhauses von Berlin Nr. 104. Drucksache 6/1593 [Report on urban renewal in 1973]. Berlin: Senatsverwaltung Berlin.

Senator für Bau- und Wohnungswesen Berlin. (Eds.). (1978). Internationale Bauausstellung Berlin 1984 [Resolution of the International Building Exhibition 1984]. Berlin: Senatsverwaltung Berlin.

Städtebauförderungsgesetz. (1971). Gesetz über städtebauliche Sanierungs- und Entwicklungsmaßnahmen in den Gemeinden [Law for the promotion of urban renewal]. Bundesgesetzblatt, 72, 1125-1156.

Städtebauliche Bestätigung (Reg.-Nr. 204/81). (1981, October 9). [Planning confirmation]. Magistrat von Berlin, Chefarchitekt (C Rep. 110-01 Nr. 4619). Landesarchiv Berlin, Germany.

Stimmann, H. (1985). Stadterneuerung in Ost-Berlin vom "sozialistischen Neuaufbau" zur "komplexen Rekonstruktion" [Urban renewal from "socialist constructions" to "complex reconstruction" in East Berlin]. Berlin: Hörnicke-Druck.

Stimmann, H. (2009). Städtebau vom Europäischen Jahr des Denkmalschutzes) bis heute [Town planning since the European year of monument protection until today]. In H. Bodenschatz, J. Düwel, N. Gutschow, \& H. Stimmann (Eds.), Berlin und seine Bauten, Teil I: Städtebau [Berlin and its structures. Part 1: Town planning] (pp. 357-456). Berlin: DOM Publishers.

Topfstedt, T. (1999). Wohnen und Städtebau in der DDR [Housing and town planning in GDR]. In I. Flagge (Ed.), Geschichte des Wohnens. Band 5: 1945 bis heute Aufbau Neubau Umbau [History of housing. Part 5: 1945 until today construction, new-construction, reconstruction] (pp. 419-561). Stuttgart: Deutsche Verlags-Anstalt. 
Wakeman, R. (2014). Rethinking post-war planning history. Planning Perspectives, 29(2), 153-163.

Warnke, S. (2009). Stein gegen Stein. Architektur und Medien im geteilten Berlin 1950-1970 [Brick versus brick. Architecture and media in divided Berlin 1950-1970]. Frankfurt and New York, NY: CampusVerlag.

Wehland, G. (1983). Stadtplanung, Partizipation und kommunale Öffentlichkeit. Zum politischen Stellenwert von bürgerschaftlicher Mitwirkung im Bauleitplanverfahren [Urban planning, participation, and the municipal public. The political relevance of civic engagement in urban land-use planning]. Berlin:
Universitäts-Bibliothek TU Berlin.

Wittmann-Englert, K. (Ed.). (2015). Radikal Modern. Planen und Bauen im Berlin der 1960er Jahre [Radically modern. Planning and constructing Berlin during the 1960s]. Tübingen and Berlin: Ernst Wasmuth Verlag.

Zache, M. (2000). Von der "sozialistischen Erneuerung" zur "komplexen Rekonstruktion" [From "socialist renewal" to "complex reconstruction"]. In Architektenund Ingenieur-Verein zu Berlin (Ed.), Visionen einer besseren Stadt: Städtebau und Architektur in Berlin 1949-1999 [Visions of a special city. Town planning and architecture in Berlin 1949-1999] (pp. 73-76). Berlin: Kahmann Dr. \& Verl.

\section{About the Authors}
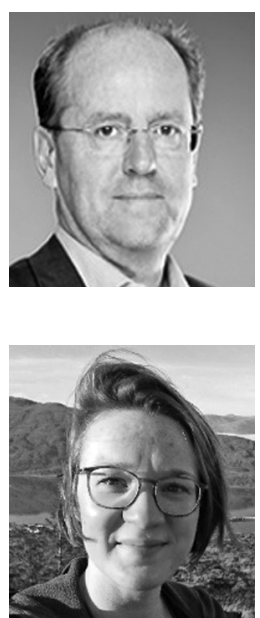

Christoph Bernhardt (PhD) is Head of the Department for Historical Research and Deputy Director at the Leibniz-Institute for Research on Society and Space (IRS). At the same time, he is an Adjunct Professor for Modern and Contemporary History at the Department of History at Humboldt Universität Berlin, Faculty of Arts and Humanities. Despite others, he leads as principal investigator the project "The Mediatisation of Urban Development Planning and Changes to the Public Sphere" (MedPlan) since 2017. His research interests are the building and planning history of the GDR, the history of mobility studies as well as urban restructuring and renewal.

Kathrin Meissner (MA) works as Research Associate since 2017 in the MedPlan project at the IRS. She is conducting her PhD thesis on the significance and transformation of public communication in planning cultures of East and West Berlin between 1975 and 1989. Trained as an urban historian and human geographer her research focusses on planning cultures, visual planning, civic engagement, colonial planning in Portuguese dictatorship, and the history of the urban narrative 'Berliner Mietskaserne.' 